\title{
ANALISIS KESALAHAN SISWA DALAM MENYELESAIKAN SOAL CERITA ARITMATIKA SOSIAL BERDASARKAN PROSEDUR NEWMAN
}

\section{(ANALYSIS OF STUDENT ERRORS IN RESOLVING THE PROBLEM OF SOCIAL ARITMATIC STORIES BASED ON NEWMAN PROCEDURES)}

\author{
Fahmi Abdul Halim ${ }^{1}$, Nilta Ilmiyatul Rasidah ${ }^{2}$ \\ ${ }^{1}$ Dosen Prodi Pendidikan Matematika STKIP PGRI Lumajang, \\ fahmi_abdul_halim@yahoo.com \\ ${ }^{2}$ Mahasiswa Prodi Pendidikan Matematika STKIP PGRI Lumajang, \\ nilta@yahoo.com
}

\begin{abstract}
Abstrak
Penelitian ini bertujuan untuk mendeskripsikan kesalahan dan menganalisis faktor penyebab kesalahan yang dilakukan siswa kelas VII H SMP Negeri 2 Lumajang dalam menyelesaikan soal cerita matematika pokok bahasan aritmatika sosial berdasarkan prosedur Newman. Jenis penelitian ini adalah penelitian kualitatif deskriptif. Subjek penelitian ini berjumlah 30 siswa. Teknik pengumpulan data menggunakan tes tulis dan wawancara. Hasil analisis data yang diperoleh kesalahan memahami masalah sebanyak $39,17 \%$ termasuk tingkat kesalahan cukup tinggi, kesalahan transformasi sebanyak 76,67\% termasuk tingkat kesalahan sangat tinggi, kesalahan keterampilan proses sebanyak 20,83\% termasuk tingkat kesalahan kecil dan kesalahan penulisan jawaban akhir sebanyak $80,83 \%$ termasuk tingkat kesalahan sangat tinggi. Berdasarkan uraian diatas dapat disimpulkan bahwa masih banyak siswa kelas VII H SMP Negeri 2 Lumajang yang melakukan kesalahan dalam menyelesaikan soal cerita matematika pada materi aritmatika sosial.
\end{abstract}

Kata Kunci: Analisis Kesalahan, Soal Cerita, Prosedur Newman

\begin{abstract}
This study aims to describe the errors and analyze the causes of errors made by students of class VII $H$ of SMP Negeri 2 Lumajang in solving mathematical story problems on the subject of social arithmetic based on the Newman procedure. This type of research is descriptive qualitative research. The subjects of this study amounted to 30 students. Data collection techniques using written tests and interviews. The results of data analysis obtained errors of Comprehension as much as $39.17 \%$ including the error rate is quite high, transformation errors as much as $76.67 \%$ including very high error rates, process skills errors as much as $20.83 \%$ including small error rates and Encoding error was $80.83 \%$ including a very high error rate. Based on the description above, it can be concluded that there are still many class VII H students of Lumajang 2 State Junior High School who make mistakes in solving math story problems in social arithmetic material.
\end{abstract}

Keywords: Error Analysis, Story Problems, Newman Procedure 


\section{PENDAHULUAN}

Matematika merupakan pengetahuan universal yang mendasari perkembangan teknologi modern yang mempunyai peran penting dalam mengembangkan daya pikir manusia, serta sebagai sarana komunikasi sains tentang pola-pola untuk melatih berpikir logis, kritis, kreatif, dan inovatif (BSNP, 2006:123). Hudojo (2003:40) mengatakan bahwa matematika adalah suatu alat untuk mengembangkan cara berpikir, sehingga matematika sangat diperlukan baik untuk kehidupan sehari-hari maupun dalam menghadapi kemajuan IPTEK. Oleh karena itu, matematika merupakan pengetahuan yang penting untuk diajarkan disekolah.

Menurut Cornelius (dalam Abdurrahman, 2003:253), lima alasan perlunya belajar matematika karena matematika merupakan (1) sarana berpikir yang jelas dan logis, (2) sarana untuk menyelesaikan masalah kehidupan seharihari, (3) sarana mengenal pola-pola hubungan dan generalisasi pengalaman, (4) sarana untuk mengembangkan kreativitas, dan (5) sarana untuk meningkatkan kesadaran terhadap perkembangan budaya. Dengan demikian, salah satu kemampuan matematika yang penting untuk dimiliki oleh siswa adalah kemampuan menyelesaikan masalah dalam bentuk soal cerita.

Hudojo (2003:151) juga mengatakan bahwa penyelesaian masalah harus dipelajari oleh setiap siswa, karena dalam menyelesaikan masalah siswa harus memahami proses penyelesaiannya terlebih dahulu. Siswa yang memahami proses penyelesaian masalah akan terampil dalam memilih dan mengidentifikasikan kondisi dan konsep yang relevan. Siswa juga akan terampil mencari generalisasi, merumuskan rencana penyelesaian dan mengorganisasikan keterampilan yang telah dimiliki sebelumnya. Berdasarkan data PISA tahun 2009 (dalam Wijaya, 2012:1-2), diperoleh hasil bahwa hampir setengah siswa Indonesia $(43,5 \%)$ tidak mampu menyelesaikan soal PISA paling sederhana. Sekitar sepertiga siswa Indonesia yaitu $(33,1 \%)$ hanya bisa mengerjakan soal dari soal kontekstual yang diberikan secara eksplisit serta semua data yang dibutuhkan untuk mengerjakan soal diberikan secara tepat. Hanya $0,1 \%$ siswa Indonesia mampu mengembangkan dan mengerjakan pemodelan matematika yang menuntut keterampilan berpikir dan penalaran.

Salah satu alat yang dapat digunakan untuk menganalisis kesalahan siswa adalah dengan prosedur Newman. Menurut Jha (2012:17) Newman menyarankan lima kegiatan yang spesifik, yaitu membaca (reading), memahami (comprehension), transformasi (transformation), keterampilan proses (process skill), dan penulisan (encoding).

Observasi awal yang dilakukan oleh peneliti saat melakukan wawancara dengan guru bidang studi matematika di SMP Negeri 2 Lumajang, didapatkan hasil wawancara sebagai berikut: (1) Siswa masih kurang memahami konsep materi aritmatika sosial, (2) Masih banyak siswa yang salah dalam menyelesaikan soal-soal operasi pada aritmatika sosial terutama dalam bentuk uraian. Hanya 5 dari 32 siswa yang memiliki kemampuan pemahaman konsep dan pemahaman bernalar yang baik dilihat dari proses kegiatan belajar mengajar saat berlangsung dan dari hasil ulangan siswa. Pemberian soal ulangan khususnya soal cerita di kelas VII SMP Negeri 2 Lumajang jarang dilakukan.

Berikut ini adalah contoh kesalahan hasil pengerjaan salah satu siswa :. 


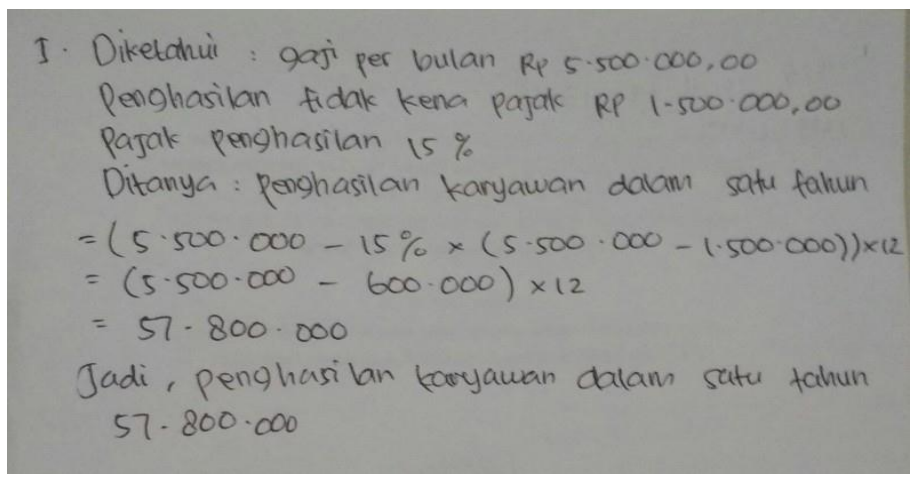

Gambar 1. Contoh Kesalahan Siswa dalam Tahapan Analisis Newman

Pada gambar 1 di atas menunjukkan bahwa siswa sudah melakukan tahapan analisis Newman, siswa sudah menuliskan informarsi apa yang diketahui dan ditanyakan dengan benar. Pada tahapan transformasi siswa masih belum menuliskan pendekatan atau rumus yang akan digunakan. Pada keterampilan proses siswa sudah bisa menghitung tetapi masih belum tepat seharusnya 5.500.000 $-600.000=4.900 .000$ lalu dikali 12 dan hasilnya 58.800.000, tapi siswa menuliskan dengan hasil 57.800.000 sehingga siswa melakukan kesalahan keterampilan proses karena proses perhitungan salah sehingga siswa menarik kesimpulan pun juga masih belum tepat.

Dengan demikian, untuk mengetahui kesalahan yang dilakukan siswa dalam menyelesaikan soal cerita khususnya materi Aritmetika Sosial perlu dilakukan analisis terhadap kesalahan yang dilakukan siswa sehingga kesalahan yang mereka lakukan dapat diminimalisir. Prosedur Newman digunakan untuk menganalisis kesalahan siswa dalam menyelesaikan soal cerita materi aritmetika social, sehingga prosedur Newman ini diharapkan dapat mengetahui variasi kesalahan siswa dan faktor-faktor yang menjadi penyebab kesalahan yang dilakukan siswa

Beberapa penelitian mengenai masalah menyelesaikan soal cerita matematika yaitu penelitian yang dilakukan oleh Putri (2008), terungkap bahwa kesalahan yang sering dialami siswa seperti 1) Tidak paham konsep-konsep sederhana, 2) Tidak mengetahui maksud soal, 3) Tidak bisa menerjemahkan soal ke dalam kalimat matematika, 4) Tidak bisa menyelesaikan kalimat matematika, 5) Tidak cermat dalam menghitung, dan 6) Kesalahan dalam menulis angka. Menurut Budiyono (2008:7) menyatakan bahwa soal cerita masih merupakan soal yang cukup sulit bagi sebagian siswa. Seng (2009) mengatakan bahwa banyak siswa melakukan kesalahan dalam hal menyederhanakan dan mengoperasikan bentuk aljabar. Nabila (2016) juga mengatakan bahwa kesalahan siswa dalam menyelesaikan soal cerita adalah mengenai kesalahan mengidentifikasi antara apa yang diketahui dengan apa yang ditanyakan dalam soal.

Berdasarkan uraian di atas, untuk menemukan dan mengetahui kesalahan kesalahan yang dilakukan siswa dalam menyelesaikan soal cerita matematika. Salah satu materi yang dianggap sesuai dengan masalah tersebut adalah Aritmetika Sosial. Maka perlu dilaksanakan penelitian dengan judul "Analisis Kesalahan Siswa dalam Menyelesaikan Soal Cerita Aritmatika Sosial Berdasarkan Prosedur Newman". 


\section{KAJIAN TEORI \\ Analisis Kesalahan}

Dalam Kamus Bahasa Indonesia (2008:60), analisis adalah penyelidikan suatu peristiwa (karangan, perbuatan dan sebagainya) untuk mengetahui apa sebab-sebabnya, bagaimana duduk perkaranya, dan sebagainya. Sedangkan kesalahan dalam Kamus Bahasa Indonesia (2008:1247), adalah kekeliruan, perbuatan yang salah (melanggar hukum dan sebagainya). Jadi analisis kesalahan adalah sebuah upaya penyelidikan terhadap suatu peristiwa penyimpangan untuk mencari tahu apa yang menyebabkan suatu peristiwa penyimpangan itu bisa terjadi.

Dalam pembelajaran, seorang guru sebaiknya melakukan analisis terhadap kesalahan yang dilakukan oleh siswa. Analisis yang dilakukan berupa mencari tahu jenis dan penyebab kesalahan siswa. Menurut Legutko (dalam Satoto, 2012:22) mengatakan bahwa "pentingnya dilakukan analisis kesalahan sebagai berikut: ... dalam kegiatan pembelajaran, guru harus benar-benar menganalisis kesalahan siswa, mencoba untuk memahami kesalahan, menjelas kanapa yang mereka alami, dan menemukan apa yang menyebabkan kesalahan itu terjadi”.

\section{Soal Cerita Bentuk Uraian}

Soal cerita merupakan salah satu bentuk soal yang menyajikan permasalahan dalam kehidupan sehari-hari dalam bentuk narasi atau cerita. Soal cerita biasanya diwujudkan dalam kalimat yang di dalamnya terdapat persoalan atau permasalahan yang penyelesaiannya menggunakan keterampilan berhitung (Budiyono, 2008:8). Dalam menyelesaikan soal cerita, terlebih yang berupa soal uraian, siswa diharapkan dapat menuliskan serta menjelaskan secara runtut proses penyelesaian masalah yang diberikan dengan cara memilih dan mengidentifikasi kondisi dan konsep yang relevan, mencari generalisasi, merumuskan rencana penyelesaian dan mengorganisasi keterampilan yang telah dimiliki sebelumnya (Hartini, 2008:28). Dalam soal cerita berbentuk uraian, siswa mengerjakannya dengan menentukan terlebih dahulu apa yang diketahui, ditanya, dan menuliskan secara jelas dan rinci jawabannya.

\section{Prosedur Newman}

Metode analisis kesalahan Newman diperkenalkan pertama kali pada tahun 1977 oleh Anne Newman, seorang guru mata pelajaran matematika di Australia. Menurut Prakitipong \& Nakamura (2006:113), prosedur Newman adalah sebuah metode untuk menganalisis kesalahan dalam soal uraian. Menurut Jha (2012:17) dalam kajiannya mengemukakan bahwa Newman menyarankan lima kegiatan yang spesifik, yaitu membaca (reading), memahami (comprehension), transformasi (transformation), keterampilan proses (process skill), dan penulisan (encoding).

Jha (2012), White (2005), dan singh (2010) memberikan beberapa factor dan indikator yang menjadi penyebab siswa melakukan kesalahan dalam menyelesaikan soal bentuk uraian yang didasarkan pada prosedur Newman. Adapun tabel faktor dan indikator penyebab siswa melakukan kesalahan adalah: 
Tabel 1. Faktor dan Indikator Kesalahan Siswa

\begin{tabular}{|c|c|c|}
\hline No. & $\begin{array}{l}\text { Faktor Penyebab Kesalahan } \\
\text { Siswa }\end{array}$ & Indikator \\
\hline \multirow{2}{*}{1} & \multirow{2}{*}{ Reading (membaca) } & $\begin{array}{l}\text { a. Siswa tidak mampu membaca atau mengenali } \\
\text { simbol dalam soal }\end{array}$ \\
\hline & & $\begin{array}{l}\text { b. Siswa tidak mampu memaknai arti setiap } \\
\text { kata, istilah atau simbol dalam soal }\end{array}$ \\
\hline \multirow{2}{*}{2} & \multirow{2}{*}{ Comprehension (memahami) } & $\begin{array}{l}\text { a. Siswa tidak memahami informasi apa saja } \\
\text { yang diketahui dalam soal dengan lengkap }\end{array}$ \\
\hline & & $\begin{array}{l}\text { b. Siswa tidak memahami apa saja yang } \\
\text { ditanyakan dalam soal dengan lengkap }\end{array}$ \\
\hline \multirow{3}{*}{3} & \multirow{3}{*}{ Transformation (transformasi) } & $\begin{array}{l}\text { a. Siswa tidak mampu membuat model } \\
\text { matematis dari informasi yang didapatkan }\end{array}$ \\
\hline & & $\begin{array}{l}\text { b. Siswa tidak mengetahui rumus yang akan } \\
\text { digunakan untuk menyelesaikan soal }\end{array}$ \\
\hline & & $\begin{array}{l}\text { c. Siswa tidak mengetahui operasi hitung yang } \\
\text { akan digunakan untuk menyelesaikan soal }\end{array}$ \\
\hline 4 & $\begin{array}{c}\text { Process Skill (pemahaman } \\
\text { proses) }\end{array}$ & $\begin{array}{l}\text { a. Siswa tidak mengetahui prosedur } \\
\text { ataulangkah-langkah yang r akan } \\
\text { digunakanuntuk menyelesaikan soal dengan } \\
\text { tepat }\end{array}$ \\
\hline \multirow{3}{*}{5} & \multirow{3}{*}{ Encoding (penulisan jawaban) } & $\begin{array}{l}\text { a. Siswa tidak mampu menemukan hasil akhir } \\
\text { dari soal berdasarkan prosedur atau langkah- } \\
\text { langkah yang telah digunakan }\end{array}$ \\
\hline & & $\begin{array}{l}\text { b. Siswa tidak dapat menunjukan jawaban akhir } \\
\text { dari penyelesaian soal dengan benar }\end{array}$ \\
\hline & & $\begin{array}{l}\text { c. Siswa tidak dapat menuliskan jawaban akhir } \\
\text { sesuai dengan kesimpulan }\end{array}$ \\
\hline
\end{tabular}

White (dalam Haryati, 2015) menunjukkan tipe-tipe kesalahan menurut prosedur Newman yang mungkin dilakukan siswa dalam menyelesaikan soal matematika, meliputi kesalahan karena ketidakcermatan, kesalahan membaca soal, kesalahan dalam memahami soal, kesalahan mentransformasikan, kesalahan dalam keterampilan proses, kesalahan dalam penulisan.

\section{METODE PENELITIAN}

Penelitian ini menggunakan penelitian deskriptif dengan pendekatan kualitatif. Penelitian ini menghasilkan data deskriptif berupa kata-kata tertulis atau lisan dari siswa yang diamati. Menurut Moleong (2011:6), penelitian kualitatif adalah penelitian yang bermaksud untuk memahami fenomena tentang apa yang dialami oleh subjek penelitian misalnya perilaku, persepsi, motivasi, tindakan, dll, secara holistik, dan dengan cara deskripsi dalam bentuk kata-kata dan bahasa pada suatu konteks khusus yang alamiah dan dengan memanfaatkan berbagai metode ilmiah. Sedangkan penelitian deskriptif menurut Narbuko (dalam Romadhoni, 2017), yaitu penelitian yang berusaha untuk menuturkan pemecahan masalah berdasarkan data-data, selain itu juga menyajikan data, menganalisis, dan menginterpretasikan data tersebut. Sumber data pada penelitian ini adalah siswa kelas VII H SMP Negeri 2 Lumajang. Prosedur pengumpulan data menggunakan tes dan wawancara. Analisis data menggunakan deskriptif kualitatif. Analisis deskriptif kualitatif adalah pengelolaan data dalam bentuk katakata bukan berupa data statistik. Analisis data dalam penelitian ini adalah dengan menggunakan metode analisis kesalahan menurut Newman, yaitu analisis jawaban dari tes tertulis yang sudah diberikan pada siswa.

\section{HASIL DAN PEMBAHASAN}

Berdasarkan hasil pekerjaan siswa maka hasil analisis kesalahan berdasarkan prosedur Newman dapat dilihat pada tabel berikut. 
Tabel 2. Analisis Jenis Kesalahan Siswa dalam Menyelesaikan Soal Cerita

\begin{tabular}{|c|l|c|c|}
\hline No. & \multicolumn{1}{|c|}{ Jenis Kesalahan } & Persentase & Kategori \\
\hline 1 & Kesalahan Membaca & $0,00 \%$ & Sangat Kecil \\
\hline 2 & Kesalahan Memahami & $39,17 \%$ & Cukup Tinggi \\
\hline 3 & Kesalahan Transformasi & $76,67 \%$ & Sangat \\
\hline 4 & Kesalahan Keterampilan Proses & $20,83 \%$ & Kecil \\
\hline 5 & $\begin{array}{l}\text { Kesalahan Penulisan Jawaban } \\
\text { Akhir }\end{array}$ & $80,83 \%$ & $\begin{array}{c}\text { Sangat } \\
\text { Tinggi }\end{array}$ \\
\hline
\end{tabular}

Berdasarkan Tabel 2, maka diperoleh besar persentase untuk jenis kesalahan siswa dalam menyelesaikan soal cerita pada materi Aritmatika Sosial yaitu:

1 Kesalahan Membaca (Reading Error) sebanyak 0,00\% maka termasuk tingkat kesalahan sangat kecil.

2 Kesalahan Memahami (Comprehension Error) sebanyak 39,17\% maka termasuk tingkat kesalahan cukup tinggi.

3 Kesalahan Tansformasi (Transformation Error) sebanyak 76,67\% maka termasuk tingkat kesalahan sangat tinggi.

4 Kesalahan Keterampilan Proses (Process Skill Error) sebanyak 20,83\% maka termasuk tingkat kesalahan kecil.

5 Kesalahan Penulisan Jawaban Akhir (Encoding Error) sebanyak $80,83 \%$ maka termasuk tingkat kesalahan sangat tinggi.

Berikut adalah hasil petikan tes dan wawancara yang dilakukan oleh subjek penelitian:

1. Subjek Penelitian 1

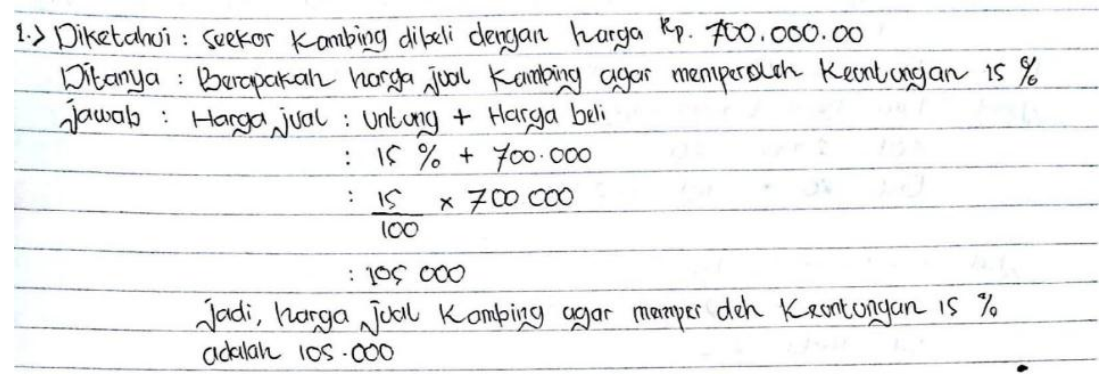

Gambar 2. Hasil Pekerjaan Subjek Penelitian 1

Langkah untuk menyelesaikan soal dengan menggunakan prosedur Newman. Hanya saja pada langkah keterampilan proses dan penulisan jawaban akhir siswa masih melakukan kesalahan.

Berikut petikan hasil wawancara peneliti dengan siswa

Peneliti : Bagian mana yang salah?

Siswa : (Menunjukkan bagian yang salah pada bagian perhitungan harga jual).

Peneliti : Bagian itu kenapa salahnya?

Siswa : Penjumlahannya salah, Bu. Seharusnya ditambahkan dengan harga.

Berdasarkan hasil tes dan wawancara dapat disimpulkan bahwa siswa melakukan jenis kesalahan keterampilan proses dan penulisan jawaban akhir. 
2. Subjek Penelitian 2

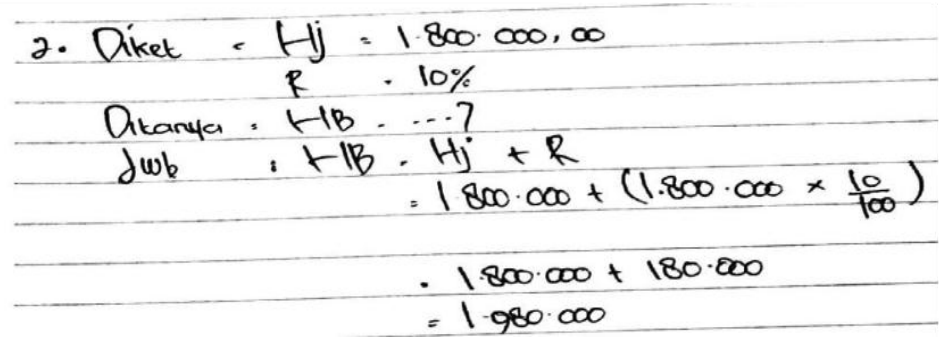

Gambar 3. Hasil Pekerjaan Subjek Penelitian 2

Dari Gambar 3, dapat dilihat bahwa siswa sudah melakukan langkahlangkah untuk menyelesaikan soal dengan menggunakan prosedur Newman. Hanya saja pada langkah transformasi, keterampilan proses dan penulisan jawaban akhir siswa masih melakukan kesalahan.

Berikut petikan hasil wawancara peneliti dengan siswa:

Peneliti : Rumus apa yang kamu gunakan?

Siswa $: \mathrm{Hb}=\mathrm{Hj}+$ Persentase kerugian.

Peneliti : Lalu seharusnya bagaimana rumus yang harus digunakan?

Siswa : $H b=\frac{100 \% \text { e }}{100 \% \text {-persentase kerugian }} \times \mathrm{Hj}, \mathrm{Bu}$.

Berdasarkan hasil tes dan wawancara dapat disimpulkan bahwa kesalahan yang dilakukan oleh siswa adalah kesalahan transformasi, keterampilan proses, dan penulisan jawaban akhir.

3. Subjek Penelitian 3

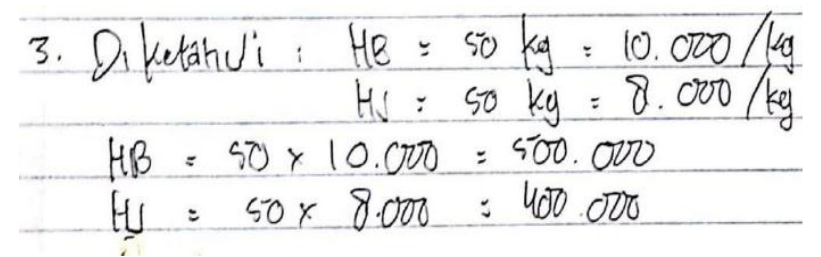

Gambar 4. Hasil Pekerjaaan Subjek Penelitian 3

Dari Gambar 4, dapat dilihat bahwa siswa sudah melakukan langkahlangkah untuk menyelesaikan soal dengan menggunakan prosedur Newman. Hanya saja pada langkah transformasi, keterampilan proses dan penulisan jawaban akhir siswa masih melakukan kesalahan.

Berikut petikan hasil wawancara peneliti dengan siswa

Peneliti : Kenapa kamu tidak mengerjakan sampai selesai?

Siswa : Waktunya habis, Bu.

Berdasarkan hasil tes dan wawancara dapat disimpulkan bahwa kesalahan yang dilakukan siswa adalah kesalahan transformasi, keterampilan proses, dan penulisan jawaban akhir. 
4. Subjek Penelitian 4

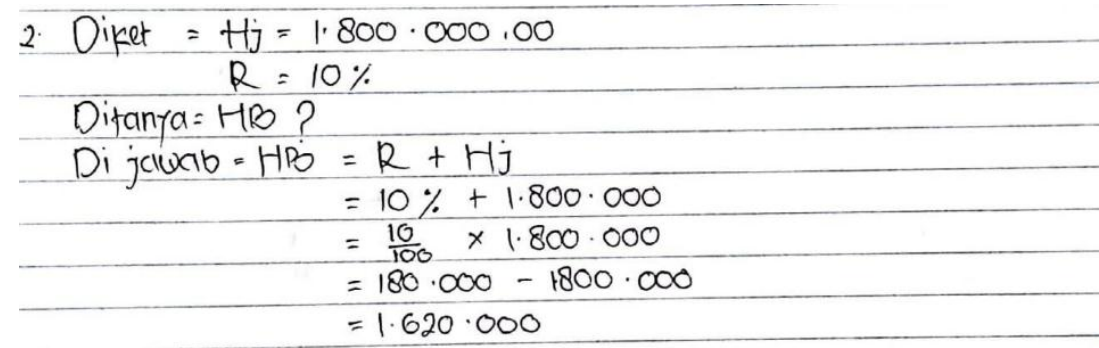

Gambar 5 Hasil Pekerjaaan Subjek Penelitian 4

Dari Gambar 5, dapat dilihat bahwa siswa sudah melakukan langkahlangkah untuk menyelesaikan soal dengan menggunakan prosedur Newman. Hanya saja pada langkah keterampilan proses dan penulisan jawaban akhir siswa masih melakukan kesalahan.

Berikut petikan hasil wawancara peneliti dengan siswa

Peneliti : Jika Persentase kerugian 10\%. Maka berapa persen sisa kerugian tersebut?

Siswa : $90 \%, \mathrm{Bu}$.

Peneliti : Seharusnya bagaimana rumus yang kamu gunakan?

Siswa : Berarti, $H b=\frac{100 \%}{100 \% \text {-persentase kerugian }} \times H j$

Berdasarkan hasil tes dan wawancara dapat disimpulkan bahwa kesalahan yang dilakukan siswa adalah kesalahan keterampilan proses dan penulisan jawaban akhir.

5. Subjek Penelitian 5

$$
\text { 3. } \begin{aligned}
H B & =10.000 \times 50=500.000,00 \\
H J & =8.000 \times 50=\frac{400.000 .00}{100.000 .00}
\end{aligned}
$$

Gambar 6. Hasil Pekerjaaan Subjek Penelitian 5

Dari Gambar 6, dapat dilihat bahwa siswa berusaha melakukan langkahlangkah untuk menyelesaikan soal dengan menggunakan prosedur Newman. Hanya saja pada langkah transformasi, keterampilan proses, dan penulisan jawaban akhir siswa masih melakukan kesalahan.

Berikut petikan hasil wawancara peneliti dengan siswa:

Peneliti : Kenapa tidak menuliskan apa yang diketahui dan ditanyakan?

Siswa : Saya tidak terbiasa mengerjakan seperti itu.

Peneliti : Kenapa kamu tidak melakukan proses perhitungan sampai selesai?

Siswa : Saya tidak tau caranya.

Berdasarkan hasil tes dan wawancara dapat disimpulkan bahwa kesalahan yang dilakukan siswa adalah kesalahan transformasi, keterampilan proses dan penulisan jawaban akhir. 
6. Subjek Penelitian 6

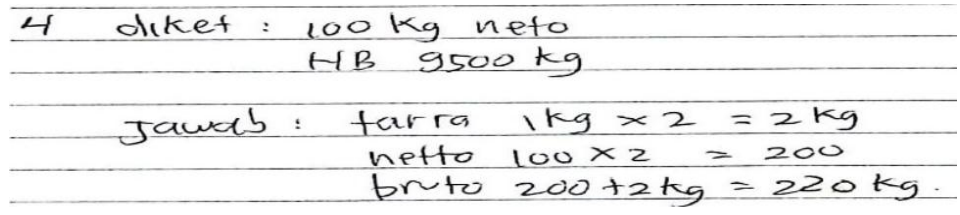

Gambar 7 Hasil Pekerjaaan Subjek Penelitian 5

Dari Gambar 7, dapat dilihat bahwa siswa hanya menuliskan langkah keterampilan proses saja. Berikut petikan hasil wawancara peneliti dengan siswa:

Peneliti : Kenapa hanya menuliskan proses perhitungan saja?

Siswa : Terburu-buru, waktunya habis, Bu.

Berdasarkan hasil tes dan wawancara dapat disimpulkan bahwa siswa melakukan jenis kesalahan memahami, transformasi, keterampilan proses, dan penulisan jawaban akhir.

\section{SIMPULAN DAN SARAN}

Berdasarkan uraian hasil analisis di atas, kesalahan-kesalahan siswa yang dianalisis sebangian besar dimulai dari kesalahan memahami masalah, kesalahan transformasi, kesalahan keterampilan proses dan penulisan jawaban akhir. Hasil analisis diperoleh dari jenis kesalahan setiap item soal pada analisis kesalahan prosedur Newman yaitu: (1) Pada kesalahan memahami masalah memperoleh persentase sebesar $39,17 \%$ termasuk tingkat kesalahan cukup tinggi, dengan jumlah 4 siswa pada soal nomor 1, 3 siswa pada soal nomor 2, 19 siswa pada soal nomor 3, dan 21 soal pada soal nomor 4, (2) Pada kesalahan transformasi memperoleh persentase sebesar 76,67\% termasuk tingkat kesalahan sangat tinggi, dengan jumlah 15 siswa pada soal nomor 1, 26 siswa pada soal nomor 2, 21 siswa pada soal nomor 3, dan 30 siswa pada soal nomor 4, (3) Pada kesalahan keterampilan proses memperoleh persentase sebesar $20,83 \%$ termasuk tingkat kesalahan kecil, dengan jumlah 3 siswa pada soal nomor 1, 12 siswa pada soal nomor 2, 8 siswa pada soal nomor 3, dan 1 siswa pada soal nomor 4, dan (4) Pada kesalahan penulisan jawaban akhir memperoleh persentase sebesar $80,83 \%$ termasuk tingkat kesalahan sangat tinggi, dengan jumlah 18 siswa pada soal nomor 1, 27 siswa pada soal nomor 2, 22 siswa pada soal nomor 3, dan 30 siswa pada soal nomor 4.

Pada kesalahan penulisan jawaban akhir memperoleh persentase sebesar $80,83 \%$ termasuk tingkat kesalahan sangat tinggi, dengan jumlah 18 siswa pada soal nomor 1, 27 siswa pada soal nomor 2, 22 siswa pada soal nomor 3, dan 30 siswa pada soal nomor 4.

Penyebab dari kesalahan tersebut yaitu siswa tidak terbiasa menuliskan apa yang diketahui dan ditanyakan pada soal, siswa tidak dapat menentukan metode atau rumus yang akan digunakan unttuk menyelesaikan permasalahannya, siswa kurang teliti dalam melakukan proses perhitungan untuk menyelesaikan permasalahan, dan siswa tidak terbiasa menuliskan atau menarik kesimpulan pada jawaban akhir. 


\section{DAFTAR RUJUKAN}

Abdurrahman, M. 2003. Pendidikan Bagi Anak Berkesulitan Belajar. Jakarta: Penerbit Rineka Cipta.

Budiyono. 2008. Kesalahan Mengerjakan Soal Cerita dalam Pembelajaran Matematika.11(1): 1-8.(Online). (https://eprints.uns.ac.id), di akses 23 Februari 2018

BSNP. 2006. Standar Isi untuk Satuan Pendidikan Dasar dan Menengah. Jakarta: Badan Standar Nasional Indonesia.

Haryati, Tuti. 2015. Analisis Kesalahan Siswa Smp Kelas VII Dalam Menyelesaikan Soal Cerita Pemecahan Masalah Berdasarkan Prosedur Newman.(Online). (http://lib.unnes.ac.id/22328/1/4101411066-s.pdf) di akses 18 November 2017

Hudojo, H. 2003. Pengembangan Kurikulum dan Pembelajaran Matematika. Malang: FMIPA Universitas Negeri Malang.

Jha, S. K. 2012. Mathematics Performance ofPrimary School Students in Assam (India): An Analysis Using Newman Procedure. International Journal of Computer Applicationsin Engineering Sciences, 2(1): 17-21. (Online). (http://connection.ebscohost.com) diakses 22 Februari 2018.

Kamus Besar Bahasa Indonesia. 2008. (Online). (http://bahasa.kemdiknas.go.id/kbbi/index.php) diakses 22 Februari 2018

Krismanto. 2009. Modul Matematika SMP Program Bermutu: Kapita Selekta pembelajaran Aljabar di Kelas VII SMP. Sleman:PPPPTK Matematika.

Moleong, L.J. 2011. Metodologi Penelitian Kualitatif. Jakarta: Remaja Rosdakarya.

Putri W, Mella. 2008. Analisis Kesulitan Menyelesaikan Soal Cerita Pada Pelajaran Matematika Kelas VII Semester Ganjil SMP Tri Sukses Natar Tahun Ajaran 2008/2009.Skripsi tidak diterbitkan. Lampung: Unila.

Romadhoni, 2017. Identifikasi Kesalahan Siswa Berkecerdasan Visual Spasial Dalam Menyelesaikan Soal Matematika Bangun Ruang Sisi Datar. Skripsi tidak diterbitkan. Jember: Fakultas Keguruan Dan Ilmu Pendidikan Universitas Jember

Satoto, Seto., dkk. 2012. Analisis Kesalahan Hasil Belajar Siswa dalam Menyelesaikan Soal dengan Prosedur Newman. Unnes Journal of Mathematics Education. Semarang: Universitas Negeri Semarang. (Online). (http://lib.unnes.uad.ac.id/18693/1/4101408090.pdf) diakses pada tanggal 25 Februari 2018.

Singh, dkk. 2010. The Newman Procedure for Analyzing Primary Four Pupils Errors on Written Mathematical Task: A Malaysian Perspective. Shah Alam: University Technologi MARA

Seng, Lim Kok. (2009). An Error Analisys of from 2 (Grade 7) Student Simplifying Algebraic Expressions: A Descriptive Study. Electronic Journal of Research in educational Psycology. 8(1): 139-162

Ulya, Qurotaa'yun. 2016. Analisis Kesalahan Siswa dalam Menyelesaikan Soal Cerita Persamaan Linier Satu Variabel. Skripsi tidak diterbitkan . Surakarta: FKIP Universitas Muhammadiyah Surakarta

Wijaya, Ariyadi. 2012. Pendidikan Matematika Realistik. Yogyakarta: Graha Ilmu. 